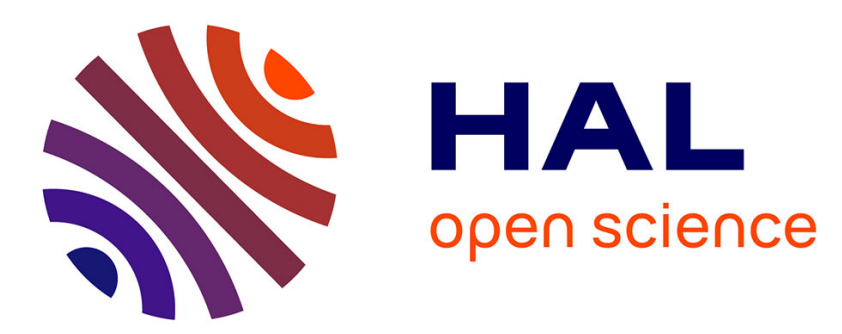

\title{
Picosecond spectroscopy of transition-metal-ion-doped solid state laser materials
}

\author{
V. Mikhailov, N. Kuleshov
}

\section{To cite this version:}

V. Mikhailov, N. Kuleshov. Picosecond spectroscopy of transition-metal-ion-doped solid state laser materials. Journal de Physique IV Proceedings, 1994, 04 (C4), pp.C4-594-C4-594. 10.1051/jp4:19944145 . jpa-00252600

\section{HAL Id: jpa-00252600 https://hal.science/jpa-00252600}

Submitted on 1 Jan 1994

HAL is a multi-disciplinary open access archive for the deposit and dissemination of scientific research documents, whether they are published or not. The documents may come from teaching and research institutions in France or abroad, or from public or private research centers.
L'archive ouverte pluridisciplinaire HAL, est destinée au dépôt et à la diffusion de documents scientifiques de niveau recherche, publiés ou non, émanant des établissements d'enseignement et de recherche français ou étrangers, des laboratoires publics ou privés. 


\title{
Picosecond spectroscopy of transition-metal-ion-doped solid state laser materials
}

\author{
V.P. MIKHAILOV and N.V. KULESHOV
}

International Laser Center, Belarusian State University, Kurchatov Str. 7, Minsk 220064, Belarus

\begin{abstract}
The development of tunable solid state lasers requires a detailed and quantitative understanding of relaxation processes in excited states of impurity ions in crystals.

Recently, the kinetics of nonradiative transitions from the excitedstates to metastable storage level was investigated in ruby, alexandrite, emerald and $\mathrm{T} i$-sapphire $[1,2]$. An upper limit of 7 ps was obtained for the ${ }^{4} \mathrm{~T}_{2}$ state nonradiative lifetime of $\mathrm{Cr}^{3+}$ in ruby. In alexandrite and emerald the nonradiative relaxation time of $17 \mathrm{ps}$ and 23 ps for intra ${ }^{4} \mathrm{~T} 2$ vibrational transitions and $27 \mathrm{ps}$ and $20 \mathrm{ps}$ for the ${ }^{4} \mathrm{~T}_{2}-{ }^{2} \mathrm{E}$ electronic transition were measured. An upper limit of $3.5 \mathrm{ps}$ for the intra ${ }^{2} \mathrm{E}_{\mathrm{g}}$ state vibrational relaxation time in $\mathrm{T} i$-sapphire was estimated.

The obtaining of laser action on chromium-doped farsterite and YAG in the near infrared excites great interest to $\mathrm{Cr}^{4+}$ and other tetrahedrally coordinated ions in crystalline hosts. In this paper saturation of absorption and relaxation processes in excited states of the tetrahedrally coordinated $\mathrm{Cr}^{4+}$ in garnets and forsterite, $\mathrm{V}^{3+}$ in YAG and $\mathrm{Co}^{2+}$ in GSGG are investigated. Absorption cross section of the ${ }^{3} \mathrm{Az}_{2}-{ }^{3} \mathrm{~T} 2$ transition was measured to be $5 \times 10^{-18} \mathrm{~cm}^{2}$ and $2.3 \times 10^{-18} \mathrm{~cm}^{2}$ for the $\mathrm{Cr}^{4+}$ in garnets and forsterite, respectively, and $8 \times 10^{-18} \mathrm{~cm}^{2}$ for the $V^{3+}$ in YAG. An upper limit for the intra $\mathbf{3}_{2}$ state vibrational relaxation time was estimated to be $8 \mathrm{ps}$ for the $\mathrm{Cr}^{4+}$ in garnets and $15 \mathrm{ps}$ for the $\mathrm{Cr}^{4+}$ in forsterite and $\mathrm{V}^{3+}$ in YAG. Nonradiative lifetime of the ${ }^{4} \mathrm{~T}_{1}\left({ }^{4} \mathrm{P}\right)$ and ${ }^{4} \mathrm{~T}_{1}\left({ }^{4} \mathrm{~F}\right)$ excited states of the Co ${ }^{+}$: GSGG was estimated to be approximately 35 and $20 \mathrm{ps}$.

Q-switched and mode-locked laser pulses have been obtained for a number of solid state lasers in the near infrared $(747 \mathrm{~nm}-1.34$ $\mu^{\mathrm{m}}$ ) using chromium-doped crystals and V:YAG as the saturable absorbers.
\end{abstract}

References

1. S.K. Gayen, W.B. Wang, V. Petricevic et al, Appl. Phys. Lett. 47 (1985) 455, 49 (1986) 437, 50 (1987) 1484.

2. S.K. Gayen, W.B. Wang, V. Petricevic, S.G. Demos, and R.R. Alfano, J. Lumin. 47 (1991) 